\title{
Anna Gawrońska-Piotrowska
}

\author{
Uniwersytet Kardynała Stefana Wyszyńskiego w Warszawie
}

\section{Serial audio w Polsce jako nowoczesna forma słuchowiska radiowego}

\section{Audio series in Poland as a modern form radio play}

\begin{abstract}
ABSTRAKT
Słuchowisko radiowe powstało w dwudziestoleciu międzywojennym jako połączenie radia z literaturą. Przez dziesiątki lat ewoluowało, by dotrzeć do czasów współczesnych i próbować odnaleźć się w przestrzeni internetu.

Nowym zjawiskiem, obecnym od kilku lat wśród form dźwiękowych, jest serial audio.

Jest on postrzegany jako nowoczesny teatr dźwiękowy. Celem niniejszego artykułu jest omówienie i przedstawienie specyfiki polskiego serialu audio oraz ukazanie sposobu, $\mathrm{w}$ jaki realizuje on ideę nowoczesnych słuchowisk. Aby zrealizować ten cel w pierwszej kolejności zdefiniowano pojęcie słuchowiska radiowego wraz z jego charakterystyką. Następnie ukazano ogólną charakterystykę serialu audio w Polsce, by w kolejnej części artykułu przejść do wskazania i analizy zawartości popularnych przykładów polskiego serialu audio.
\end{abstract}

SŁOWA KLUCZOWE:

serial audio w Polsce, słuchowisko radiowe, format audio

\begin{abstract}
The radio play was created in the Interwar period as a combination of radio and literature. Over the decades it has evolved to reach modern times and try to find its place in internet driven world. Audio series is a relatively new phenomenon that that emerged among sound forms a few years ago. It is perceived as a modern sound theater. The purpose of this article is to discuss and present the specificity of the Polish audio series and to show how it implements the idea of modern radio dramas. In order to achieve this goal, the concept of a radio play with its characteristics was first defined. Then, the general characteristics of the audio series in Poland were presented. Next part of the article, indicates and analyses content of popular Polish audio series examples.
\end{abstract}

\section{KEYWORDS:}

audio series in Poland, radio drama, audio format 


\section{WSTĘP}

Zmysł słuchu jest pierwszym, który rozwija się w człowieku. Kształtuje się już bowiem na etapie życia płodowego ${ }^{1}$. Jak podkreśla amerykański badacz dźwięku Julian Treasure, zaczynamy słyszeć już w dwunastym tygodniu po poczęciu. Choć uszy nie są jeszcze wtedy w pełni ukształtowane, zaczynamy już odbierać różnorodne przestrzenie foniczne - bicie serca matki, jej głos wraz z różnymi jego poziomami i barwą ${ }^{2}$. Owe spostrzeżenia pozwalają zauważyć ważną rolę przekazu i odbioru słuchowego w człowieku. Podobnie jest z pierwotną potrzebą opowiadania - znaną już kulturom oralnym. Z tejże potrzeby w dwudziestoleciu międzywojennym powstało słuchowisko jako połączenie radia z literaturą. Przez dziesiątki lat ewoluowało, by dotrzeć do czasów współczesnych i próbować odnaleźć się w przestrzeni internetu. Choć słuchowisko mogłoby wydawać się w czasach nowoczesnych technologii reliktem przeszłości, to próbuje ono odnaleźć swoją formę w rzeczywistości nowych mediów i ich konwergencji. Obecnie obserwujemy coraz częstsze konstatacje dotyczące rozmycia gatunkowego nowych mediów, transformacji gatunków medialnych oraz rezygnowania z identyfikacji gatunkowej na rzecz typologicznej ${ }^{3}$. Jak zauważa Grzegorz Ptaszek, rozwój i ewolucja gatunków, to „proces naturalny, wpisany w rozwój i przeobrażenia kultury - świata, dzięki któremu gatunki, rozumiane jako swoiste schematy, wzorce, istnieją i w którym funkcjonują"4. Owe przemiany gatunkowe zauważalne są w sferach różnych rodzajów mediów, nie omijając rzeczywistości audialnej. I tak oto nowym zjawiskiem, obecnym od kilku lat wśród form dźwiękowych jest serial audio. Jest on postrzegany w kulturze popularnej jako nowoczesny teatr dźwiękowy - rodzaj słuchowiska radiowego. Brakuje jednak naukowych analiz dotyczących tego zjawiska. Stąd autorka niniejszego artykułu, zauważając potrzebę rozpoczęcia naukowego dyskursu na temat serialu audio, poświęca temu tematowi swoją publikację.

${ }^{1}$ Por. J. Biewen, Inroduction [w:] Reality Radio. Telling true stories in sounds, University of North Carolina, Chapel Hill, North Carolina 2010.

${ }^{2}$ Por. J. Treasure, Sound business. How to use sound to grow profits and brand value (2nd ed.), „Journal of Business Research” 2011, nr 49(2), s. 193-211.

${ }^{3}$ Por. G. Stachyra, Perspektywy badania współczesnej genologii radiowej, „Acta Universitatis Lodziensis. Folia Litteraria Polonica" 2017, nr 39, s. 51.

${ }^{4}$ G. Ptaszek, W stronę bezgatunkowości mediów? O funkcji gatunków medialnych w procesie odbioru, [w]: Gatunki i formaty we współczesnych mediach, red. W. Godzic, A. Kozieł, J. Szylko-Kwas, Warszawa 2015, s. 37. 
Owe przemiany gatunkowe zauważalne są

w sferach różnych rodzajów mediów, nie omijając rzeczywistości audialnej. I tak oto nowym zjawiskiem, obecnym od kilku lat wśród form dźwiękowych jest serial audio. Jest on postrzegany w kulturze popularnej jako nowoczesny teatr dźwiękowy - rodzaj słuchowiska radiowego. Brakuje jednak naukowych analiz dotyczących tego zjawiska

\section{METODOLOGIA}

Przedmiotem niniejszych badań jest zawartość treściowa i forma polskich seriali audio.

Celem podjętych badań jest ukazanie i scharakteryzowanie specyfiki polskiego serialu audio oraz wskazanie w jaki sposób realizuje on ideę nowoczesnych słuchowisk. Aby zrealizować ten cel sformułowano następujące pytania badawcze: Czym jest słuchowisko radiowe? Czym jest serial audio i jak wygląda jego kondycja w Polsce? Jaka jest charakterystyka i zawartość omawianych przykładów serialu audio z rynku polskiego?

Powyższe pytania pozwalają na sformułowanie następujących hipotez badawczych:

H1 - Seriale audio są nowoczesną formą słuchowiska radiowego, wykorzystujące formy multimedialne.

H2 - Seriale audio są przygotowane w wysokiej jakości merytorycznej i technicznej.

Celem sformułowania odpowiedzi na pytania badawcze i zweryfikowania postawionych hipotez, w pierwszej kolejności zdefiniowane zostanie pojęcie słuchowiska radiowego wraz ze wskazaniem jego cech oraz umiejscowienia wśród gatunków medialnych. Następnie ukazana zostanie ogólna charakterystyka serialu audio oraz kondycja tej formy dźwiękowej w Polsce, by w kolejnej części 
artykułu przejść do analizy zawartości wybranych przykładów polskiego serialu audio. Do badania wybrano popularne seriale audio powstałe między 2018 a 2021 rokiem. W celu wybrania seriali audio do analizy wpisano w Google.com hasło „Seriale audio w Polsce”. W rezultacie wybrano pięć tego typu produkcji, które znalazły się wśród najwyżej spozycjonowanych wyników z pierwszych dwóch stron wyszukiwania.

Na końcu przedstawione zostaną wnioski wraz ze wskazaniem, w jaki sposób seriale audio realizują idee nowoczesnych słuchowisk radiowych, a także zaproponowane zostaną kierunki dalszych badań.

\section{SŁUCHOWISKO RADIOWE - DEFINICJA I CHARAKTERYSTYKA}

Odwołując się do istniejących prób teoretycznego opisu słuchowiska, należy zauważyć, iż wpisują się one w binarną typologię stanowisk badawczych: logocentryzmu i fonocentryzmu ${ }^{5}$. Logocentrycy przyznają prymat słowu, zaś fonocentrycy za najważniejszą uznają akustykę i dźwięk ${ }^{6}$. Jak podkreślają badaczki Joanna Bachura i Aleksandra Pawlik, echa dyskusji z dwudziestolecia międzywojennego między przedstawicielami tych dwóch nurtów pobrzmiewają do dziś. Zauważają jednocześnie, iż praktyka pokazuje, że zarówno słowo, jak i warstwa akustyczna są ważnymi elementami słuchowiska, które jest konstrukcją wielotworzywową .

Pochylając się nad umiejscowieniem słuchowiska wśród gatunków radiowych, Elżbieta Pleszkun-Olejniczakowa zauważa, iż medioznawcy często pomijają ten byt w swoich rozważaniach nad genologią gatunków audialnych ${ }^{8}$. Badaczka przywołuje interesującą prezentację gatunków radiowych autorstwa Bogusława Nierenberga ze „Słownika wiedzy o mediach” ${ }^{2}$, w której brakuje jednak wzmianki o słuchowisku radiowym. Pleszkun-Olejniczakowa snuje przypuszczenie, że być

${ }^{5}$ J. Łastowiecki, Specyfika odbioru słuchowiska radiowego, Toruń 2019, s. 28.

${ }^{6}$ J. Bachura, A. Pawlik, Słuchowisko i jego „anatomia”, [w:] red. E. Pleszkun-Olejniczakowa, J. Bachura, A. Pawlik, Dwa Teatry. Studia z zakresu teorii i interpretacji sztuki słuchowiskowej, Toruń 2011, s. 142.

${ }^{7}$ Zob. tamże, s. 142-143.

${ }^{8}$ Zob. E. Pleszkun-Olejniczakowa, Jak jest zrobione słuchowisko? O morfologii i znaczeniu, o kreacji i znaku, [w:] red. E. Pleszkun-Olejniczakowa, J. Bachura, A. Pawlik, Dwa teatry. Studia z zakresu teorii i interpretacji sztuki słuchowiskowej, Toruń 2011, s. 65.

${ }_{9}^{9}$ Zob. Słownik wiedzy o mediach, red. E. Chudziński, Warszawa-Bielsko Biała 2007. 
może „autor uznał, iż ten byt audialny nie daje się zmieścić w określeniu «dziennikarski»?”10. Z kolei w innej ważnej pozycji - „Słowniku Terminologii Medialnej” - słuchowisko określone jest inaczej jako „dramat radiowy” oraz „gatunek z pogranicza”, który „bywa radiową adaptacją utworu scenicznego lub opiera się na tekście oryginalnym, dopuszcza wielość konwencji i stylów"11. Katarzyna Albińska zauważa, iż słuchowisko radiowe, wymykając się ramom gatunkowym, nazywane bywa m.in. „teatrem do słuchania”, „literaturą do grania” czy „kinem dla ucha”12. Z tego względu badaczka nazywa słuchowisko „specyficznym gatunkiem radiowym” ${ }^{\prime 3}$. Agnieszka Szlachta natomiast określając słuchowiska „artystycznymi sztukami radiowymi”, podkreśla „niejednoznaczną naturę tego gatunku i konieczność sięgania do dorobku teoretycznego różnych dyscyplin”"14. Jej zdaniem są one „powiązane m.in. z takimi pokrewnymi dziedzinami jak literatura, teatr, kino, czerpią również inspiracje ze sztuk wizualnych"15. Odnosząc się do ontologii teatru radiowego Szlachta stwierdza, iż koniecznym warunkiem do zaistnienia artystycznych dzieł radiowych jest wykorzystanie wyłącznie tworzywa fonicznego $\mathrm{z}$ uwzględnieniem fonetyczno-semantycznych reguł jego organizacji ${ }^{16}$.

Jedna z pierwszych i często cytowanych definicji słuchowiska autorstwa Michała Kaziowa podkreśla, iż na foniczność tego dzieła artystycznego składają się: „głos, mówione słowo, cisza, muzyka, odgłosy natury, głosy ptaków i zwierząt, odgłosy uruchamianych przedmiotów, wielopłaszczyznowa przestrzeń akustyczna"17. Badacz podkreśla również, że akcja słuchowiska „konstytuuje się jako imaginatywna rzeczywistość w wytwórczej wyobraźni słuchacza"18.

${ }^{10}$ E. Pleszkun-Olejniczakowa, Jak jest zrobione słuchowisko?..., dz. cyt., s. 65.

${ }^{11}$ W. Pisarek, Słownik Terminologii Medialnej, Kraków 2006, s. 198.

${ }^{12}$ Zob. K. Albińska, «Teatr do słuchania», «literatura do grania», «kino dla ucha»: o rodowodzie gatunkowym słuchowiska radiowego, „Kultura i Historia” 2012, nr 21, http://kulturaihistoria.umcs.lublin.pl/archives/3400 (dostęp 3.06.2021 r.).

${ }^{13}$ Zob. Tamże.

${ }^{14}$ A. Szlachta, Językowe wykładniki kreacji świata przedstawionego w słuchowisku Krzysztofa Bizia pt. «Fotoplastykon», „Studia Językoznawcze” 2019, t. 18, s. 144.

15 Tamże.

${ }^{16}$ Por. Tamże.

${ }^{17}$ M. Kaziów, O dziele radiowym. Z zagadnień estetyki oryginalnego słuchowiska, Wrocław - Warszawa - Kraków - Gdańsk 1973, s. 93.

${ }^{18}$ Tamże, s. 93. 
Głos aktora to jedna $\mathrm{z}$ najważniejszych składowych spektaklu radiowego. Pełni funkcję interpretującą tekst, jest przekaźnikiem dodatkowych znaczeń, ukazuje indywidualne cechy charakteru bohaterów oraz ich stan emocjonalny. Głos ma też integralny związek ze słowem. Słowo zaś zdaje się pełnić funkcję nadrzędną wobec niewerbalnych elementów fonicznych. Należy jednak podkreślić, iż w słuchowiskach to gest foniczny, będący odpowiednikiem ludzkich zachowań wizualno-dźwiękowych, pomocniczych wobec słowa, pełni istotne znaczenie. Dopełnia on zatem mowę ludzką. Wszelkie westchnienia, krzyki, chrząknięcia, zawahania, przyspieszenia oddechu akcentują sens wypowiedzi i są sugestywnym środkiem ekspresji. Oprócz słowa współistniejącego z głosem, teatr radiowy tworzą efekty dźwiękowe. Stanowią one odpowiednik warstwy wizualnej spektaklu, ukazują pozawerbalne elementy świata przedstawionego. Dopełnieniem sensu artystycznego słuchowiska jest też muzyka i cisza. Muzyka pełni nade wszystko funkcję dramaturgiczną. Twórcy posługując się nią w spektaklu radiowym chcą wywołać określone emocje w odbiorcy, ukształtować przebieg konfliktu i ukazać napięcia wewnętrzne bohaterów. Cisza nie jest w utworze dźwiękowym po prostu brakiem dźwięku, ma swoją wartość semantyczną. Wpływa na dramaturgię dzieła, buduje nastrój, kształtuje napięcie emocjonalne, jest znacznikiem czasu. Wszystkie opisane elementy tworzą w słuchowisku dźwiękową materię semiotyczną ${ }^{19}$. Agnieszka Szlachta podkreśla rolę nowoczesnych efektów dźwiękowych w budowaniu przestrzennej realizacji fabuły, co pomaga w odbiorze słuchowiska: „Precyzyjne wypowiedzi bohaterów i odpowiednio dobrane dźwiękowe rekwizyty pozwalają słuchaczowi zorientować się, jak wyglądają postaci, w jakim miejscu przestrzeni się znajdują, jaka jest pora roku czy dnia" 20 .

Twórcy słuchowisk podkreślają ogromną rolę odbiorcy spektakli radiowych, który staje się niejako współtwórcą dzieła. Janusz Łastowiecki pisze: „Słuchowisko jest taką formą kontaktu, która bardziej niż literatura pobudza wyobraźnię odbiorcy, bo ilu jest słuchaczy, tyle jest portretów bohaterów. Każdy w radiu tworzy własny wizerunek protagonistów słuchowiska, widzi ich działania w zbudowanej

${ }^{19}$ Por. J. Bachura-Wojtasik, E. Matusiak, Dźwiękowa sztuka elitarna. Szkic o słuchowisku poetyckim na podstawie wybranych utworów Janusza Kukuły, „Media-Kultura-Komunikacja Społeczna" 2020, t. 3, s. 114-115.

${ }^{20}$ A. Szlachta, Językowe wykładniki kreacji..., dz. cyt., s. 160. 
przez siebie scenografii”21. Ten sam autor stwierdza: „Paradoks [...] radiowej przestrzeni polega na tym, że w samotności słuchającego tkwi zalążek najludniejszego teatru na świecie. Jest tak, ponieważ żadna z instytucji kultury nie jest w stanie oddziaływać na tak liczne grono odbiorców, jakie tworzy się dzięki radiu oferującemu możliwość percepcji słuchowiska. Jeden z największych autorów radiowych, Andrzej Mularczyk, nazwał Teatr Polskiego Radia - «wielką wspólnotą osobnych»"22. Słuchowisko jawi się zatem według Łastowieckiego jako przestrzeń zbiorowego odbioru kultury, które jest jednocześnie indywidualnym odbiorem polem silnych ambiwalencji oraz różnorodności. Joanna Bachura-Wojtasik i Eliza Matusiak podkreślają, iż teatr radiowy nie może istnieć bez słuchacza (odbiorcy), który dodaje od siebie wiele emocji oraz subiektywnej percepcji metaforycznych obrazów. To dzięki odbiorcy odbywa się dopełnienie sensów i idei, które tworzone są poprzez scenariusz i realizacje, przefiltrowane przez wrażliwość autora i reżysera ${ }^{23}$. Karolina Albińska wskazuje zaś na dalsze zwiększenie roli odbiorcy słuchowiska ze względu na postępującą rewolucję cyfrową: „Dzięki niej dotychczasowi odbiorcy zmienili się z bezkrytycznych, niezdolnych do samodzielnego myślenia, łatwowiernych hord zwanych masą, w selektywnych, aktywnych i rozproszonych użytkowników"24.

\section{SERIAL AUDIO W POLSCE - RAMY POJĘCIOWE I CHARAKTERYSTYKA}

Serial audio jest pojęciem niezdefiniowanym i nowym. Brakuje definicji tego pojęcia w literaturze naukowej zarówno w Polsce, jak i na świecie. Według najlepszej wiedzy autorki po raz pierwszy tego pojęcia użyto na platformie Storytel ${ }^{25}$, która niejako stworzyło format o tej nazwie, przeszczepiając go $\mathrm{z}$ angielskiego „audio series”. Na stronach internetowych w języku angielskim można odnaleźć informacje m.in. na temat „audio drama” (czyli dramatu audio czy dramatu radiowego)

${ }^{21}$ J. Łastowiecki, Teatr Polskiego Radia jako Wielka Wspólnota OSOBNYCH. Spotkanie z Andrzejem Mularczykiem, „Tekstualia” 2013, nr 1 (32), s. 21.

${ }^{22}$ Tenże, Wielka wspólnota osobnych, „Tekstualia” 2013, nr 1 (32), s. 39.

${ }^{23}$ Por. J. Bachura-Wojtasik, E. Matusiak, Dźwiękowa sztuka elitarna..., dz. cyt., s. 111-127.

${ }^{24}$ K. Albińska, Słuchowisko w erze «nowego radia»: o współczesnym sposobie istnienia teatru audialnego i jego statusie, „Kultura i Edukacja” 2011, nr 1, s. 147.

${ }^{25}$ Storytel to pierwsza na świecie cyfrowa usługa abonamentowa, umożliwiająca streaming audiobooków na telefonach i tabletach, zob. https://www.storytel.com/pl/pl/o-storytel (dostęp 27.08.2021 r.). 
w odniesieniu nie tylko do słuchowisk radiowych emitowanych w radiu, ale również tych w formie podcastów ${ }^{26}$. Jednak w kontekście „audio series” to właśnie firma Storytel zaczęła jako pierwsza używać pojęcia „serial audio” i przygotowywać produkt pod tą nazwą ${ }^{27}$.

\section{W Polsce początki serialu audio sięgają 2017 roku, kiedy to wspominany Storytel wprowadził projekt Storytel Original.}

W Polsce początki serialu audio sięgają 2017 roku, kiedy to wspominany Storytel wprowadził projekt Storytel Original. Blogerka Wioleta Sadowska odnosząc się do omawianego produktu Storytel, podkreśla na swoim blogu, iż seriale audio to „seriale pisane specjalnie pod format audio". Twórcy projektu Storytel Original charakteryzując swój produkt, wskazują na jego odcinkowość: „To seriale audio, trzeba więc myśleć odcinkami - każdy powinien zawierać w sobie jakąś jedną zamkniętą opowieść/wątek, jakieś istotne wydarzenie, by słuchacze nie odnieśli wrażenia, że w tym odcinku dostali fabularny zapychacz. Ważne jest więc odpowiednie rozłożenie istotnych akcentów fabularnych i równe tempo opowieści. [...] Myślenie serialem, nie powieścią, stanowi w przypadku Storytel Original klucz do sukcesu ${ }^{28}$. Marcin Zwierzchowski odpowiedzialny za koordynację projektu Storytel Original w Polsce wskazuje na analogię seriali audio z serialami filmowymi na platformie Netflix: „Skojarzenia z Netflixem? W dużej mierze uzasadnione. Podobnie jak twórcy «House of Cards» czy «Daredevila», również w Storytel Original chcemy kojarzyć się z jednej strony z wysoką jakością, z drugiej zaś

${ }^{26}$ Por. Radio drama, „Wikipedia”, https://en.wikipedia.org/wiki/Radio_drama?fbclid=IwAR0_Lw3tkHwxJzV2jiH3yzvCmQOrEzDwYmW-seac_2A3oKqMZLCKfHSawiA; Audio drama weekly discussion thread, „Reddit.com”, https://www.reddit.com/r/audiodrama/comments/ p924zz/raudiodrama_weekly_discussion_thread_august_22/(dostęp: 27.08.2021 r.).

${ }^{27}$ Informacje pochodzą z korespondencji mailowej autorki artykułu z Marcinem Zwierzchowskim, odpowiedzialnym za koordynację projektu Storytel Original w Polsce z dnia 28.08.2021 r.

${ }^{28}$ Storytel czeka na wasze powieści w odcinkach, „Blog Poland Storytel.com”, https://blogpoland.storytel.com/2017/07/18/storytel-czeka-na-wasze-powiesci-w-odcinkach/\#more763 (dostęp: 28.08.2021 r.). 
z różnorodnością, dając słuchaczom historie każdego rodzaju, by każdy znalazł w Storytel coś dla siebie" ${ }^{29}$. W innym miejscu na swojej stronie internetowej twórcy Storytel Original zauważają, że dzięki odcinkowej formie i wciągającej fabule seriale audio idealnie wpisują się w miejski styl życia, coraz częściej towarzyszą ludziom podczas jazdy samochodem, treningu, w domu oraz w podróży. W polskich produkcjach tego typu można usłyszeć głosy znanych aktorów m.in. Borysa Szyca czy Cezarego Pazury ${ }^{30}$. Warte zauważenia jest również podkreślanie przez Storytel odczuwania wachlarza uczuć podczas odsłuchu serialu audio: „Według upublicznionych w tym roku badań, ludzie odczuwają więcej emocji słuchając tylko audio serialu niż faktycznie oglądając jego ekranową adaptację. Tętno przyspiesza, a temperatura ciała rośnie, gdy wyobraźnia ma tak duże pole do popisu"31.

\section{Twórcy Storytel Original zauważają, że dzięki odcinkowej formie i wciągającej fabule seriale audio idealnie wpisują się w miejski styl życia, coraz częściej towarzyszą ludziom podczas jazdy samochodem, treningu, w domu oraz w podróży.}

Pomysł Storytel został szybko zauważony przez innych dystrybutorów treści cyfrowych - m.in. Empik Go. Firma ta w 2019 roku również zaczęła przygotowywać seriale audio. Przeprowadza także konkurs na napisanie scenariusza, na podstawie którego powstaje serial audio. Wojciech Chmielarz, jeden z jurorów konkursu Empik Go podkreśla, iż w serialu audio nadrzędną rolę pełni dźwięk: „Przede wszystkim, kiedy piszemy scenariusz serialu audio czy słuchowiska, musimy pamiętać, że właśnie tym one są. To nie normalne teksty z podziałem na role. Tutaj trzeba pamiętać, o tym, że gramy dźwiękiem. Możemy go wykorzystać.

${ }^{29}$ Storytel jak Netflix, „Storytel.pl”, https://storytelpl.prowly.com/8587-storytel-jak-netflix (dostęp: 28.08.2021 r.).

${ }^{30}$ Por. Gwiazdy ekranu w serialach do słuchania, „Storytel.pl”, https://storytelpl.prowly. com/38809-gwiazdy-ekranu-w-serialach-do-sluchania (dostęp 30.08.2021 r.).

${ }^{31}$ Tamże. 
Dodać jako tło albo jako istotny element fabuły"32. Paweł Heba, Dyrektor Kreatywny Empik Go zauważa, iż omawianą formę wyróżnia widowiskowość i rozbudowana, nowoczesna konstrukcja, przypominająca film lub teatr: „Seriale audio, które tworzymy w Empik Go to produkcje, które zbliżają się do medium takiego jak film, czy teatr. Aktorzy wcielają się w nich w role, korzystając z całego swojego artystycznego warsztatu. My ze swojej strony staramy się dołożyć szczegółową scenę dźwiękową, efekty specjalne i oprawę muzyczną, które prowadzą słuchacza przez tę opowieść. To tworzy wyjątkowo sugestywną całość, która dla wielu staje się konkurencyjna wobec filmu czy serialu tradycyjnego" ${ }^{\prime 33}$.

\section{Warto zauważyć, że choć termin „serial audio” w Polsce jest novum, to od lat trzydziestych dwudziestego wieku w polskiej tradycji teatru radiowego obecne i mocno ugruntowane jest pojęcie „serialu radiowego", inaczej nazywanego „powieścią radiową".}

Warto zauważyć, że choć termin „serial audio” w Polsce jest novum, to od lat trzydziestych dwudziestego wieku w polskiej tradycji teatru radiowego obecne i mocno ugruntowane jest pojęcie „serialu radiowego"34, inaczej nazywanego „powieścią radiową". Bardzo precyzyjną definicję serialu radiowego podaje Aleksandra Pawlik w swojej książce „Teatr radiowy i jego gatunki”. Określa go jako „cykliczny gatunek dramaturgii radiowej, wykorzystujący słowo podawane przez aktorów i specyficzne radiowe środki wyrazu, takie jak efekty dźwiękowe, muzyka, cisza"35. Badaczka podkreśla też odcinkowość powieści radiowej. Jednocześnie zauważa, że

${ }^{32}$ Empik Go: druga edycja konkursu na scenariusz serialu audio, „Filmweb.pl”, https:// www.filmweb.pl/news/Empik+Go\%3A+Druga+edycja+konkursu+na+scenariusz+serialu+au dio-143279 (dostęp 30.08.2021 r.).

${ }^{33}$ Seriale audio czego warto słuchać tej jesieni, „Elle.pl”, https://www.elle.pl/artykul/seriale-audio-czego-warto-sluchac-tej-jesieni (dostęp:30.08.2021 r.).

${ }^{34}$ Wyróżnić można jeszcze zbliżone pojęcie „radiowej opery mydlanej”.

${ }^{35}$ A. Pawlik, Teatr radiowy i jego gatunki, Toruń 2014, s. 257. 
każdy odcinek jest samodzielny dramaturgicznie i stanowi „całość kompozycyjną, która pozostaje w zgodności przyczynowo-skutkowej z sąsiadującymi odcinkami”36. Pawlik zaznacza, że serial radiowy ukazuje historię stałej grupy bohaterów składającą się z co najmniej kilkunastu odcinków emitowanych regularnie w stacji radiowej. Stałe moduły czasowe radionoweli umożliwiają płynne włączenie odcinka w ramówkę programową radia ${ }^{37}$. Pierwszą polską powieścią radiową były „Dni powszednie państwa Kowalskich” Marii Kuncewiczowej (emisja w Polskim Radiu od 1936 do 1938 roku $)^{38}$.Od tego czasu serial radiowy w Polsce zaczął przeżywać rozkwit - szczególnie prezentując swoje realizacje na antenie Polskiego Radia. Powstało wiele tego typu serii, które były chętnie słuchane przez odbiorców. Ważne miejsce w historii polskich powieści radiowych zajmują takie sagi jak „Matysiakowie” (emisja od 15.12.1956 r.) ${ }^{39}$ i „W Jezioranach” (emisja od 29.05 .1960 r.) ${ }^{40}$, będące w pewnym sensie polskimi odpowiednikami produkcji emitowanych w brytyjskim BBC od początku lat 50 (np. „The Archers”). Łączą one dawną twórczość radionowelową z współczesną ofertą Teatru Polskiego Radia, gdyż są emitowane od czasów powojennych do dziś. Jednocześnie warto podkreślić, iż popularność seriali radiowych emitowanych w radiu analogowym współcześnie znacząco spadła. Forma ta nie jest już tak atrakcyjna dla dzisiejszego słuchacza, który żyjąc w epoce multimediów i „nowych nowych mediów” ${ }^{41}$ potrzebuje znacznie bardziej zróżnicowanych bytów medialnych do odbioru. Stąd serial audio, emitowany poza eterem - w sieci, wydaje się ciekawą kontynuacją tradycyjnego serialu radiowego w nowej odsłonie.

Powyższe rozważania pozwalają autorce artykułu na próbę sformułowania definicji serialu audio. Pojęcie to oznacza taką formę, która charakteryzuje się

${ }^{36}$ Tamże, s. 257.

${ }^{37}$ Por. Tamże.

${ }^{38}$ Por. "Dni powszednie państwa Kowalskich". Pierwsza powieść napisana dla Polskiego Radia, „Polskieradio.pl”, https://www.polskieradio.pl/39/156/Artykul/2839233,Dni-powszednie-panstwa-Kowalskich-Pierwsza-powiesc-napisana-dla-Polskiego-Radia (dostęp: 6.11.2021 r.).

${ }^{39}$ Zob. Matysiakowie - o audycji, „Polskieradio.pl”, https://www.polskieradio.pl/241/ 4717/Artykul/1598248,Matysiakowie-o-audycji (dostęp: 6.11.2021 r.).

${ }^{40}$ Zob. W Jezioranach, „Polskieradio.pl”, https://www.polskieradio.pl/357/7234/ (dostęp: $6.11 .2021 \mathrm{r}$.).

${ }^{41}$ Określenia „nowe nowe media” po raz pierwszy użył Paul Levinson, które odróżnia od „nowych mediów” ich społecznościowy charakter (por. Z. Bauer, Wstęp 2, [w]: E-gatunki. Dziennikarz w nowej przestrzeni komunikowania, red. W. Godzic, Z. Bauer, Warszawa 2015, s. 15). 
przekazem audio (jest zatem audiobookiem), ale ze względu na wykorzystanie dużej ilości nowoczesnych efektów dźwiękowych oraz muzyki, bliski jest filmowi/serialowi filmowemu i teatrowi. Cechuje go odcinkowość, ciekawa konstrukcja fabularna, równe tempo opowieści. Każdy odcinek zawiera jedną zamkniętą opowieść/wątek. Seriale audio są również niezwykle interesującą formą przekazu, ze względu na możliwość usłyszenia w dialogach głosów znanych aktorów oraz multimedialny charakter przekazu (uzupełniające przekaz filmy, grafiki, zwiastuny audio i wideo, wywiady, etc.). Ich podstawowym miejscem dystrybucji i odbioru jest internet. Jednocześnie prekursorem tego typu słuchowisk są tradycyjne emitowane w radiu analogowym seriale radiowe.

\section{Seriale audio są również niezwykle interesującą formą przekazu, ze względu na możliwość usłyszenia w dialogach głosów znanych aktorów oraz multimedialny charakter przekazu (uzupełniające przekaz filmy, grafiki, zwiastuny audio i wideo, wywiady, etc.)}

W kolejnej części opracowania przedstawiono charakterystykę wybranych polskich seriali audio w oparciu o analizę wybranych tego typu form dostępnych na platformach Storytel oraz Empik Go.

\section{WYBRANE PRZYKŁADY SERIALU AUDIO W POLSCE - PREZENTACJA I ANALIZA}

W tej części pracy zaprezentowano wybrane polskie seriale audio. Opisano je na podstawie analizy materiałów opublikowanych na wybranych platformach dystrybucji treści cyfrowych (Storytel, Empik Go), zrealizowanej na drodze indywidualnego odsłuchu/odbioru autorki w kontekście realizacji celu pracy i wysuniętych pytań badawczych. W drodze kwerendy internetowej wytypowano następujące popularne w internecie produkcje: „Autor bestsellerów”, „Random”, „Lalka”, „Fakap”, „Atak na K2”. 
„Autor bestsellerów” to serial audio produkcji Storytel Original (2018 r.) składający się z dziesięciu odcinków. Autorem scenariusza jest Marcin Ciszewski, znany głównie z pisania powieści kryminalnych oraz political i historical-fiction. Serial prezentuje historię najpopularniejszego pisarza w kraju, który jest uznawany za amanta, konesera trunków, lekkoducha. Śmiertelna diagnoza zmusza go do zweryfikowania swojej postawy życiowej. W rolę pisarza wciela się Cezary Pazura. Nie ma tu dodatkowych bohaterów. Całą narrację prowadzi w pierwszej osobie liczby pojedynczej wspomniany aktor. Interesującym zabiegiem jest to, iż premierze serialu towarzyszył filmowy zwiastun dostępny na YouTube, w którym obok Cezarego Pazury wystąpili inni aktorzy m.in. Jacek Lenartowicz i Marcin Bosak. Poniższe grafiki przedstawiają klatki filmowe ze zwiastuna filmowego (grafika 1, 2).

Zwiastun filmowy jest przygotowany w wysokiej jakości technicznej. Wedle odbioru autorki artykułu nie odbiega w tym aspekcie od trailerów kinowych.

W podobnej konwencji przygotowana została grafika do audiobooka. Jest zdjęciem jednego z ujęć ze zwiastuna filmowego (grafika 3)

Jakub Barzak z firmy Storytel podkreśla nowatorski charakter produktu jakim jest serial audio „Autor Bestsellerów”, a w szczególności przygotowanie zwiastuna filmowego do audiobooka: „Lubimy eksperymentować. Dlatego postanowiliśmy pójść o krok dalej i do produkcji serialowej audio dołożyć obraz, aby wprowadzić użytkownika w historię, jej klimat i najważniejszych bohaterów. Myślę, że Czarek Pazura wychowany na słuchowiskach z niesamowitą analizą postaci i znakomitym warsztatem, pozwala w pełni wejść w świat «Autora bestsellerów». Z naszych informacji wynika, że nikt na świecie nie produkuje jeszcze seriali audio, a co za tym idzie trailerów do nich"42. Omawiany serial audio jest nagrany i zmontowany w wysokiej jakości technicznej w studiu nagraniowym. Audiobook pozbawiony jest dodatkowej warstwy muzycznej i efektów dźwiękowych. Tworzywem jest tu jedynie głos Cezarego Pazury. Wedle opinii autorki tego artykułu po odsłuchu słuchowiska, warsztat reprezentowany przez aktora grającego w słuchowisku i jakość nagrań oraz montażu sprawia, że nie są tu potrzebne dodatkowe efekty i muzyka. Serialu audio można słuchać odpłatnie w aplikacji Storytel.

${ }^{42}$ Storytel z niezwykłą premierq serialową, „Sotrytel.pl”, https://storytelpl.prowly.com/38059-storytel-z-niezwykla-premiera-serialowa-zobacz-zwiastun-autora-bestsellerow-wideo (dostęp: 5.09.2021 r.). 

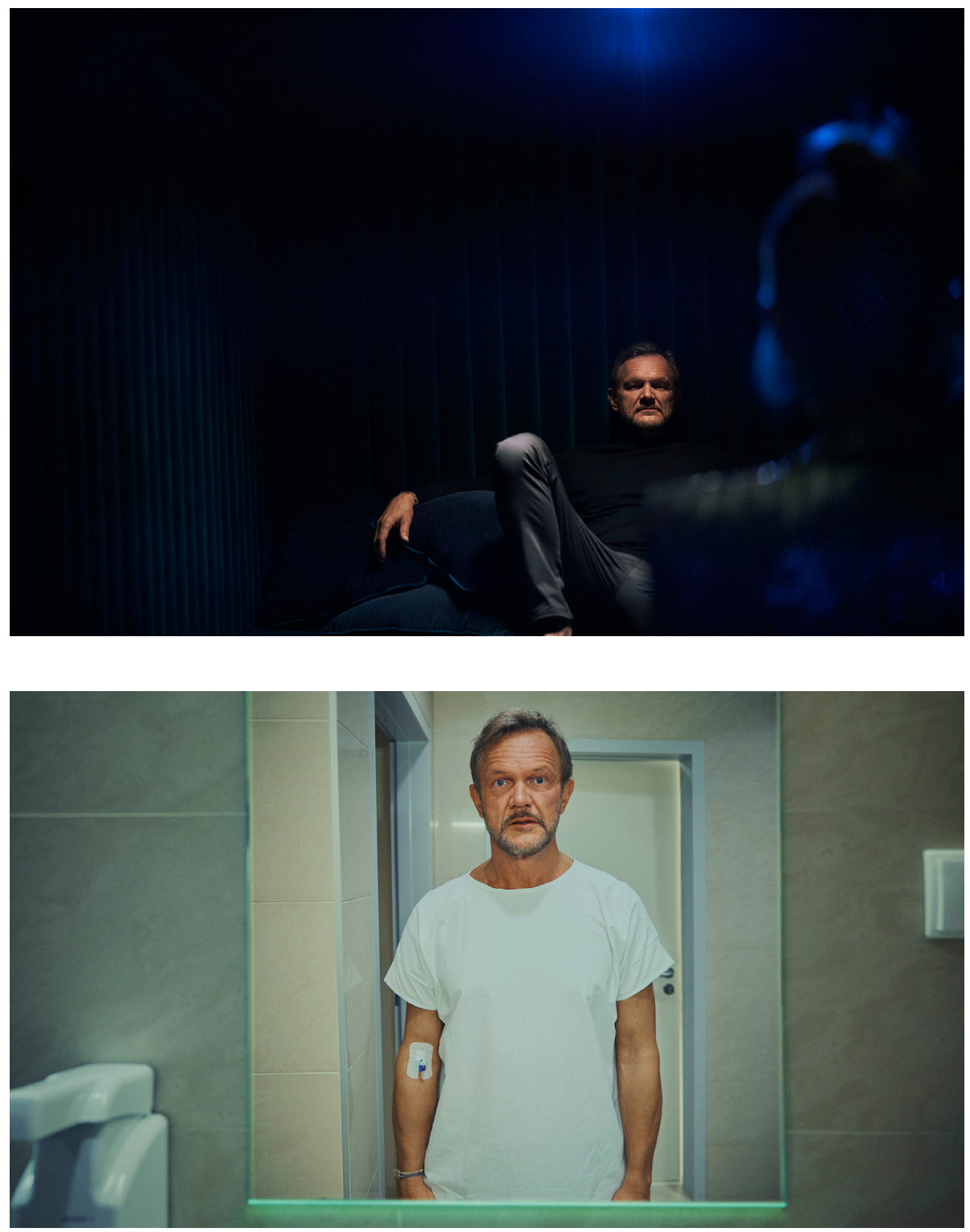

Grafika 1, 2. Klatki filmowe ze zwiastuna filmowego do serialu audio „Autor Bestselerów"

Źródło: Storytel z niezwykłą premierq serialowq, Zobacz zwiastun «Autora Bestsellerów». Wideo, „Storytel.pl”, https://storytelpl.prowly.com/38059-storytel-z-niezwykla-pre miera-serialowa-zobacz-zwiastun-autora-bestsellerow-wideo (dostęp: 5.09 .2021 r.). 


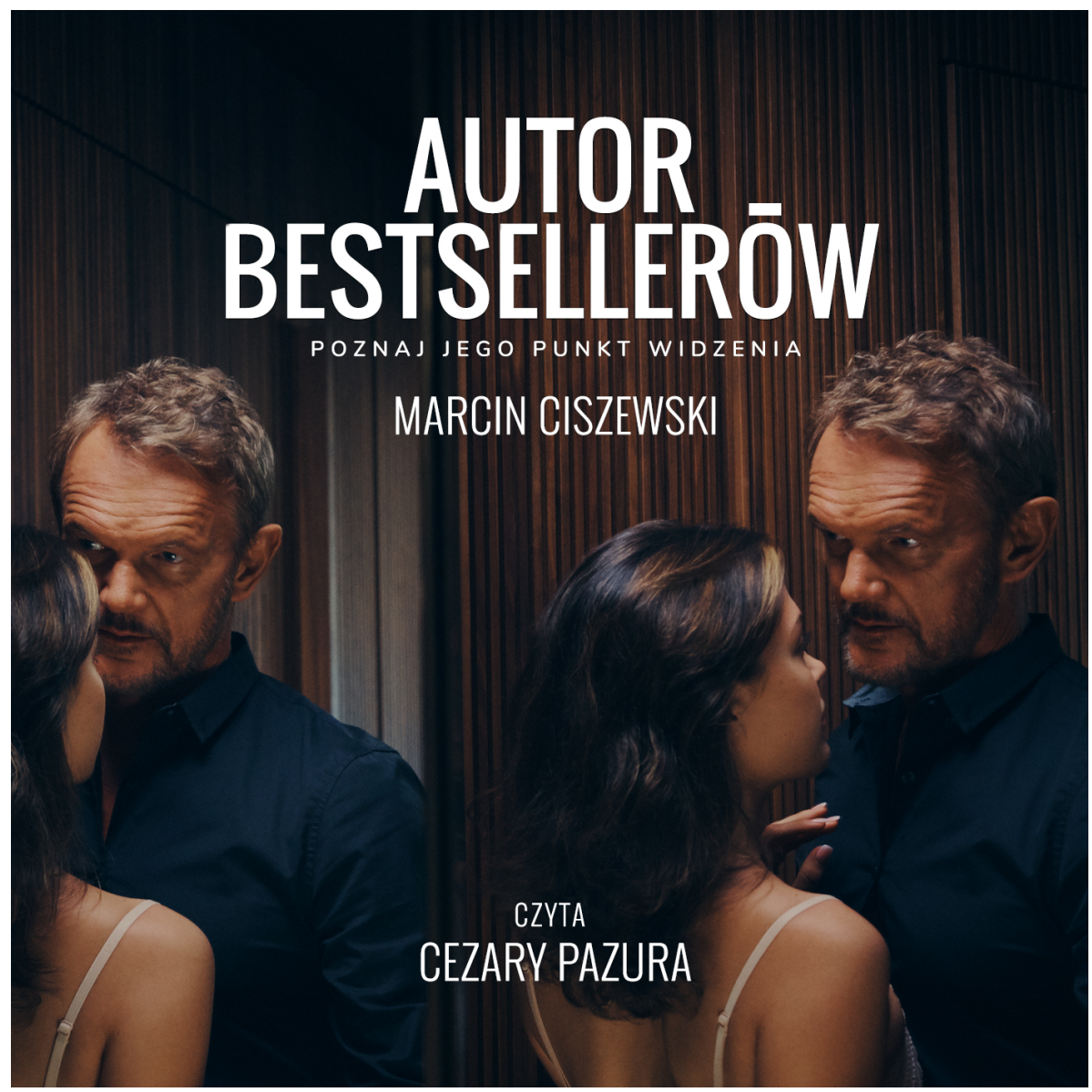

Grafika 3. Okładka do serialu audio „Autor Bestsellerów”

Źródło: Storytel z niezwykłą premierq̨ serialową... dz. cyt. (dostęp: 5.09.2021 r.).

„Random” to pięcioodcinkowa produkcja Storytel Original z 2021 roku. Autorkami scenariusza są młode reżyserki Natasza Parzymies i Alicja Sokół. Omawiany serial audio opowiada historię miłości dwojga młodych ludzi - Marii i Stasia, którzy poznają się poprzez aplikację o nazwie Random ${ }^{43}$. Występują pod pseudonimami Jantar91 i Buka12. W rolę głównych bohaterów w serialu audio wcielają się młodzi, popularni w Polsce aktorzy - Julia Wieniawa i Maciej Musiałowski. Akcja opowieści toczy się w czasie pandemii koronawirusa. Aplikacja

${ }^{43}$ Random to w rzeczywistości fikcyjna aplikacja. 
Random dobiera rozmówców losowo, na podstawie wybranej kategorii. Bohaterowie słuchowiska rozmawiają ze sobą w trybie audio, nie widząc siebie nawzajem. Codzienne problemy, pasje, marzenia - to tematy, które poruszają podczas częstych rozmów. Słuchowisko skierowane jest głównie do młodych osób, ukazując relacje dwudziestolatków w dobie nowoczesnych technologii - mediów społecznościowych i komunikatorów internetowych. Język, którego używają główni bohaterowie jest nieoficjalny, luźny, pełen kolokwializmów, nie brakuje tu wulgaryzmów i słownictwa zaczerpniętego z młodzieżowego slangu, np. „(Jantar91:) Brzmisz jak po dobrej imprezie. (Buka12:) Przyniosłem wirtualne kwiaty. (Jantar91:) Spoko, jesteś wybaczony"44. Warta omówienia jest nie tylko tematyka i język, ale także forma przekazu użyta w projekcie. Serial audio „Random” łączy pięcioodcinkowe słuchowisko w formie audio dostępne na platformie Storytel z finałową odsłoną, która jest odcinkiem filmowym na YouTube. „Kontent video w sieci jest doskonałą formą dotarcia do młodych. YouTube jest jedną z najczęściej wybieranych przez nich platform, będących źródłem wiedzy i rozrywki. Dlatego też stanowi doskonałe narzędzie do zwrócenia ich uwagi na formę słuchowiska oraz przedstawienia im oferty pobudzającej wyobraźnię i otwierającej ich na nowe kategorie doznań" ${ }^{45}$ - czytamy na stronie Wirtualnemedia.pl w kontekście odcinka finałowego „Random”. Oprócz tego materiału na kanale YouTube reżyserki Natasza Parzymies pojawiły się dwa dodatkowe filmy krótkometrażowe. Ukazują one odbiorcy świat aplikacji Random, z której korzystają główni bohaterowie opowieści. W filmach tych oprócz Julii Wieniawy i Macieja Musiałowskiego występują również znana aktorka Magdalena Boczarska, piosenkarka Katarzyna Nosowska oraz młodzi aktorzy Jan Hrynkiewicz i Sylwia Gola. Pod koniec filmów widz przekierowywany jest do omawianego słuchowiska w formie pięcioodcinkowej, dostępnego na Storytel ${ }^{46}$. Warto podkreślić, że

${ }^{44}$ Random, „Storytel.pl”, https://www.storytel.com/pl/pl/books/2173674-Random (dostęp 5.09.2021 r.).

${ }^{45}$ Random - pierwszy polski serial łączący słuchowisko i film od 14 lutego w Storytel, https://www.wirtualnemedia.pl/artykul/random-serial-laczacy-sluchowisko-i-film-storytelkiedy-premiera (dostęp 7.09.2021 r.).

${ }^{46}$ Głos młodego pokolenia - Natasza Parzymies opowiada o życiu młodych ludzi w trudnych czasach pandemii, „Storytel.pl” z 22.03.2021 r., https://storytelpl.prowly.com/132060glos-mlodego-pokolenia-natasza-parzymies-opowiada-o-zyciu-mlodych-ludzi-nbspwtrudnych-czasach-pandemii (dostęp: 7.09.2021 r.). 
grafika promująca serial audio również nawiązuje do odcinków filmowych projektu - jest ona zdjęciem jednego z ujęć wideo (grafika 4).

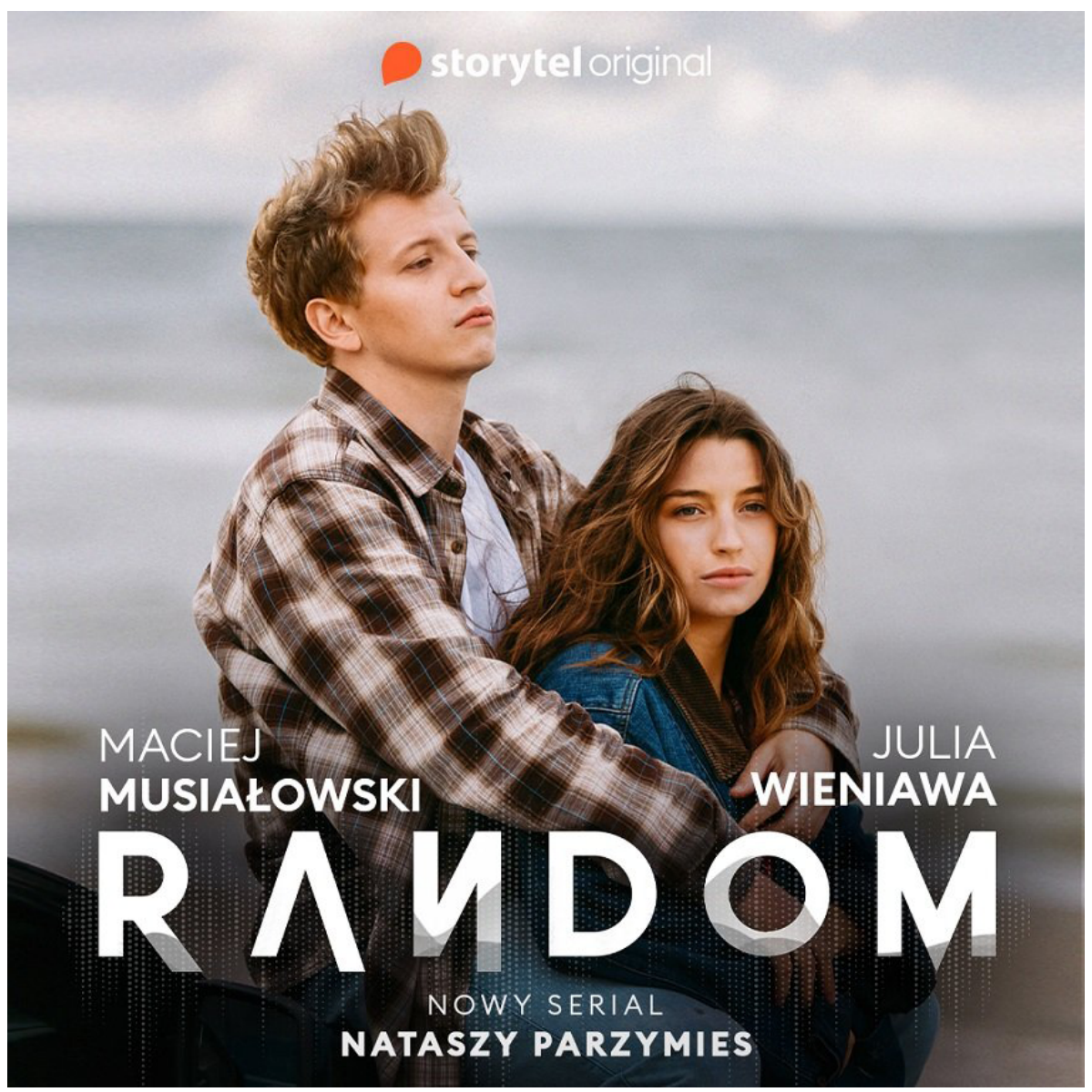

Grafika 4. Okładka do serialu audio „Random”

Źródło: Głos młodego pokolenia..., dz. cyt. (dostęp 7.09.2021 r.)

Oprócz wspomnianych elementów multimedialnych częścią projektu „Random” jest teledysk promujący opisany serial audio. To singiel, w którym śpiewa Julia Wieniawa i Maciej Musiałowski. Piosenka wykonana jest na wysokim poziomie artystycznym, sam teledysk jest również nowoczesny i w bardzo dobrej jakości technicznej. Należy zauważyć, że samo słuchowisko „Random” jest również 
przygotowane w wysokiej jakości technicznej - zarówno pod względem jakości nagrań, jak i montażu. Posiada rozbudowaną oprawę muzyczną i efekty dźwiękowe. Serialu audio można słuchać odpłatnie w aplikacji Storytel.

„Lalka” to trzynastoodcinkowy serial audio produkcji Empik.Go (2021 r.). Scenariusz oparty jest na powieści Bolesława Prusa o tym samym tytule. Projekt został dofinansowany przez Narodowe Centrum Kultury w ramach programu „Kultura w sieci”. Posiada swoją stronę internetową (lekturalalka.pl). Pomysłodawcą, reżyserem i producentem serialu audio jest Krzysztof Czeczot. Prowadzi on również narrację w słuchowisku. W rolach głównych występują znani polscy aktorzy: Julia Wieniawa (jako Izabela Łęcka), Adam Woronowicz (jako Stanisław Wokulski), Wiktor Zborowski (jako Ignacy Rzecki), Barbara Kurdej-Szatan (jako Kazimiera Wąsowska), Maciej Musiał (jako Julian Ochocki). Twórcy serialu audio podkreślają uwspółcześnienie i nowoczesne podejście do realizacji dźwiękowej W „Lalce”: „W każdej z poprzednich adaptacji «Lalki» twórcy i aktorzy eksponowali te elementy, które były najciekawsze dla współczesnych im odbiorców. Nam również zależało na tym, aby odkryć tę opowieść dla współczesnego odbiorcy, zdjąć z niej łatkę «obowiązkowej lektury maturalnej». [...] Scenariusz serialu został nieznacznie uwspółcześniony, a warstwa językowa dialogów uaktualniona. Konfrontacja realizmu krytycznego z rzeczywistością XXI wieku została przedstawiona także dzięki realizacji dźwięku, na którą złożyły się specjalne efekty 3D oraz współczesna muzyka filmowa" ${ }^{37}$. Warto podkreślić, że choć nie ma tu elementów filmowych będących wprowadzeniem, zakończeniem czy zwiastunem produkcji, to $\mathrm{w}$ ramach promocji projektu na stronie internetowej serialu audio umieszczono filmy z krótkimi wypowiedziami głównych aktorów grających w słuchowisku. Ciekawa jest też konwencja grafiki promującej serial audio. To fotografia Adama Woronowicza i Julii Wieniawy jako Wokulskiego i Izabeli Łęckiej w kostiumach zaczerpniętych ze współczesności. Grafika przypomina bilbord filmowy (grafika 5).

${ }^{47}$ Lalka Bolesława Prusa odczytana na nowo $w$ serialu audio. Wieniawa $i$ Woronowicz $w$ rolach głównych, „Empik.com” z 24.09.2020 r., https://news.empik.com/109861-lalka-boleslawa-prusa-odczytana-na-nowo-w-serialu-audio-wieniawa-i-woronowicz-w-rolachglownych (dostęp 8.09.2021 r.). 


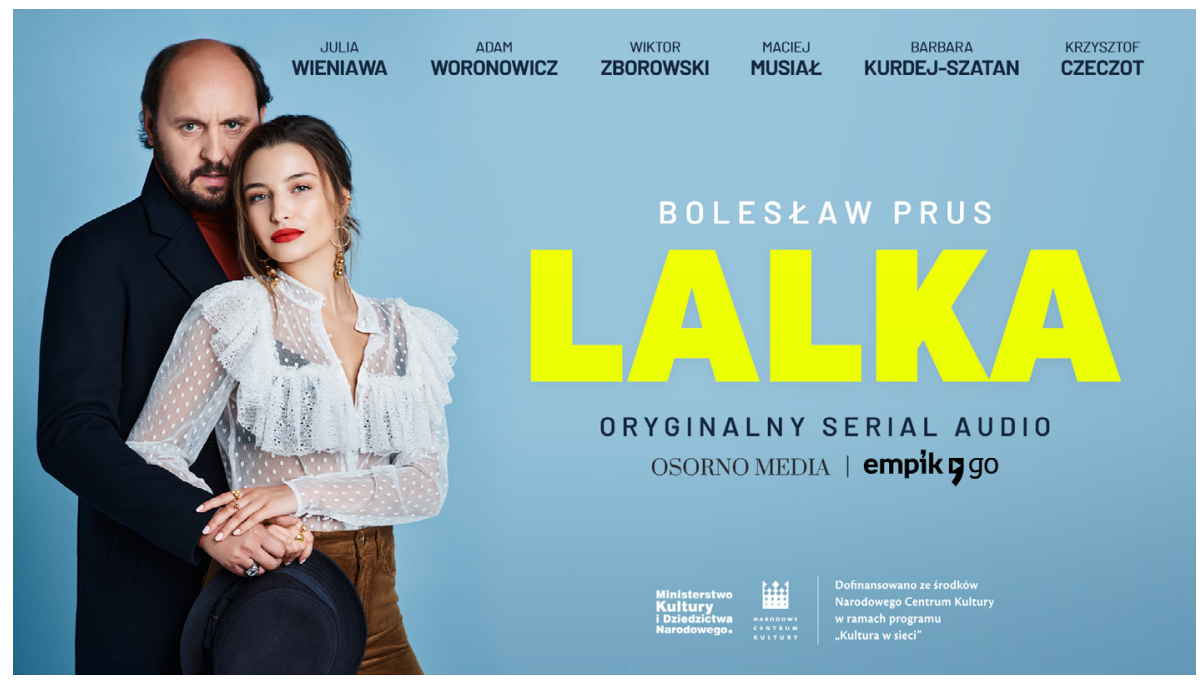

Grafika 5. Okładka do serialu audio „Lalka”

Źródło: Lalka Bolesława Prusa..., dz. cyt. (dostęp 8.09.2021 r.)

Jak zatem wskazano wcześniej, projekt pod nazwą serial audio „Lalka” zawiera wiele elementów multimedialnych - słowo, film, grafikę. Serialu audio można słuchać bezpłatnie na stronie internetowej produkcji oraz na YouTube (tu dźwięk wzbogacony jest przedstawioną wyżej grafiką 5). Odbiór jest darmowy ze względu na to, że jest to projekt dofinansowany przez instytucję państwową - Narodowe Centrum Kultury.

Kolejnym analizowanym serialem audio jest „Fakap”. To sześcioodcinkowa produkcja Empik.Go (2021 r.). Twórcy nazywają ją pierwszym komediowym serialem audio, w którym w bohaterów wcielają się aktorzy komediowi oraz, co jest kolejnym novum, polscy stand-uperzy ${ }^{48}$. Autorem pełnej absurdu i dowcipu fabuły jest stand-uper Juliusz Sipika, zaś reżyserem - Krzysztof Czeczot. Jest to historia pracowników pewnej korporacji. W role zatrudnionych w przedsiębiorstwie wcielą się między innymi aktorzy Michał Meyer, Sebastian Stankiewicz, Szymon Mysłakowski, Karolina Piechota, Michał Zieliński, Magda Smalara, Mateusz Grydlik. Przerysowane i komiczne role odgrywają stand-uperzy: Mateusz Socha,

${ }^{48}$ Stand-uper to komik wygłaszający monolog przed publicznością, zob: Stand-uper, „Słownik języka polskiego”, https://sjp.pl/standuper (dostęp 8.09.2021 r.). 


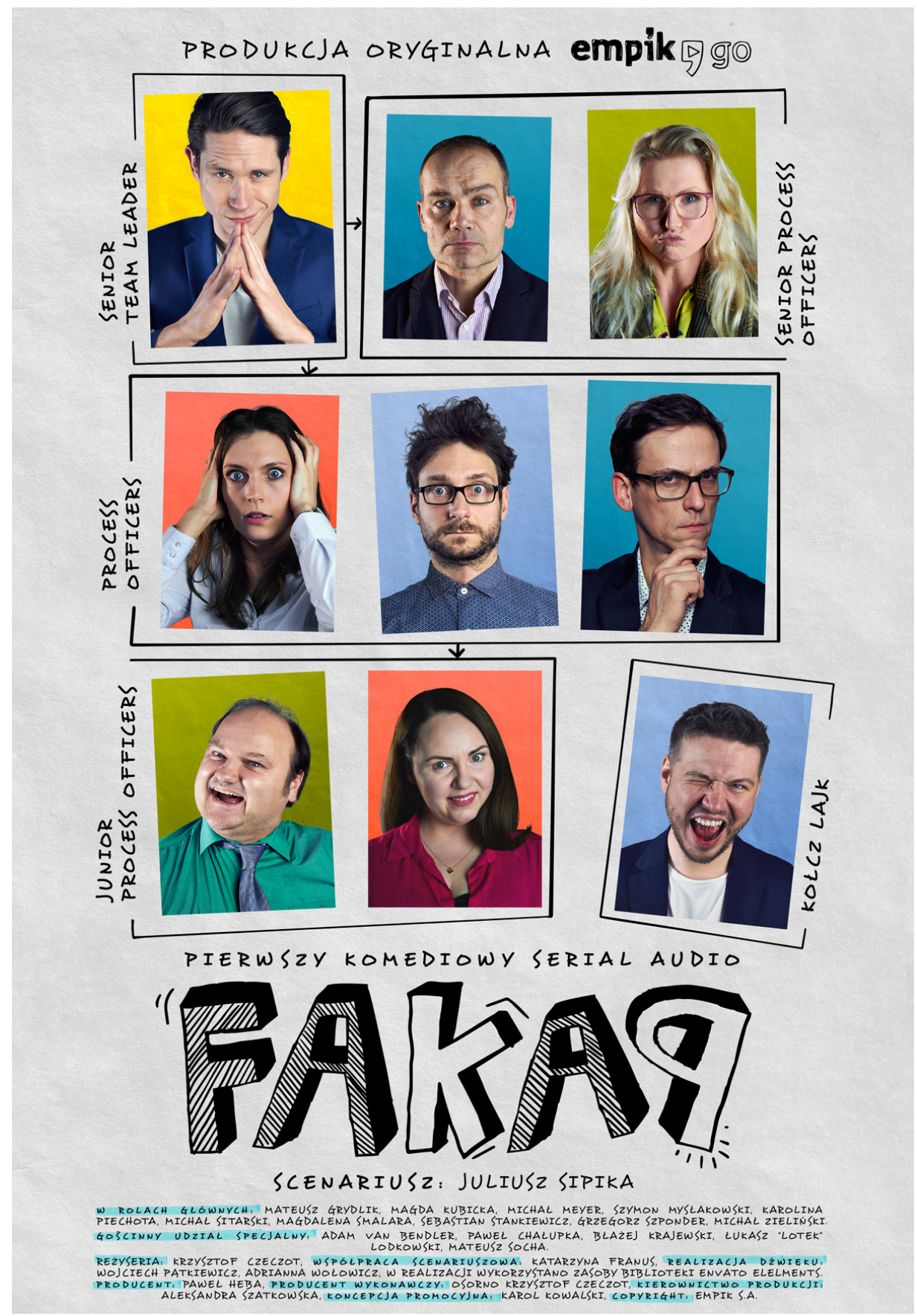

Grafika 6. Grafika promująca serial audio „Fakap”

Źródło: «Fakap». Pierwszy komediowy serial audio..., dz. cyt. (dostęp 8.09.2021 r.). 
Łukasz „Lotek” Lodkowski, Magda Kubicka, Paweł Chałupka, Błażej Krajewski i Adam van Bendler ${ }^{49}$. Wart zauważenia jest język, którego używają bohaterowie słuchowiska. Ich dialogi zawierają dużo słownictwa zaczerpniętego ze slangu korporacyjnego: „asap”, „briefing”, „deadline”, „feedback”. W dialogach słychać też język potoczny: „Kim ty jesteś? Kto ci zabrał marzenia? Czy ty dałeś dzisiaj z siebie maksa? Zaraz pójdziesz do domu usiądziesz z chipsami przed telewizorem"50. Warte zauważenia są grafiki wykorzystane do promocji serialu audio. Przedstawiają zdjęcia głównych bohaterów wraz z opisem funkcji sprawowanych w korporacji (grafika 6).

Na Youtube dostępne są także krótkie filmy z nagrań w studiu do serialu audio „Fakap”, odsyłające do słuchowiska. „Fakap” przygotowany jest w wysokiej jakości technicznej - pod względem nagrań, a także montażu i realizacji dźwiękowej. Warto wskazać, że nowatorska forma słuchowiska z udziałem stand-uperów przyciągnęła do tej formy audio odbiorców, którzy interesują się stand-upem i są fanami np. komika Mateusza Sochy czy Łukasza „Lotka” Lodkowskiego. W recenzjach odbiorcy piszą: „Przyszedłem od Sochy, nie zawiodłem się. Czekam na więcej”; „Mateusz Socha najlepszy!”, „Socha wybija Fakap ponad przeciętność”, „Couch Lajk najlepszy, dobre teksty! Czekam na odcinek z Lotkiem!"51. Serialu audio można słuchać odpłatnie w aplikacji Empik.Go.

„Atak na K2" to kolejny serial audio produkcji Storytel (2018 r.). Tu również twórcy zaskakują formą projektu i samą koncepcją. Nazywają ten projekt eksperymentalnym. Jest to pięcioodcinkowa relacja audio z wyprawy Andrzeja Bargiela, podczas której zdobył szczyt K2, a następnie jako pierwszy człowiek na świecie zjechał z niego na nartach. Katarzyna Tymczyszyn-Bębenek ze Storytel opisuje charakter nagrań jakie przesyłał na bieżąco do redakcji poprzez internet Andrzej Bargiel wraz z ekipą podczas wędrówki: „Otrzymaliśmy 5 godzin i 22 minuty surowego materiału, takiego audio pamiętnika nagrywanego przez Andrzeja

${ }^{49}$ Zob. «Fakap». Pierwszy komediowy serial audio w Polsce zadebiutuje w Empik Go, „Empik.com" z 1.03.2021 r., https://news.empik.com/129956-fakap-pierwszy-komediowy-serialaudio-w-polsce-zadebiutuje-w-empik-go (dostęp 8.09.2021 r.).

50 \#2 Fakap. Kołcz Lajk - Oryginalny Serial Empik Go, „Empik.com”, https://www.empik. com/2-fakap-kolcz-lajk-oryginalny-serial-empik-go-sipika-juliusz,p1264916919,ebooki-imp3-p (dostęp 8.09.2021 r.).

51 Tamże. 


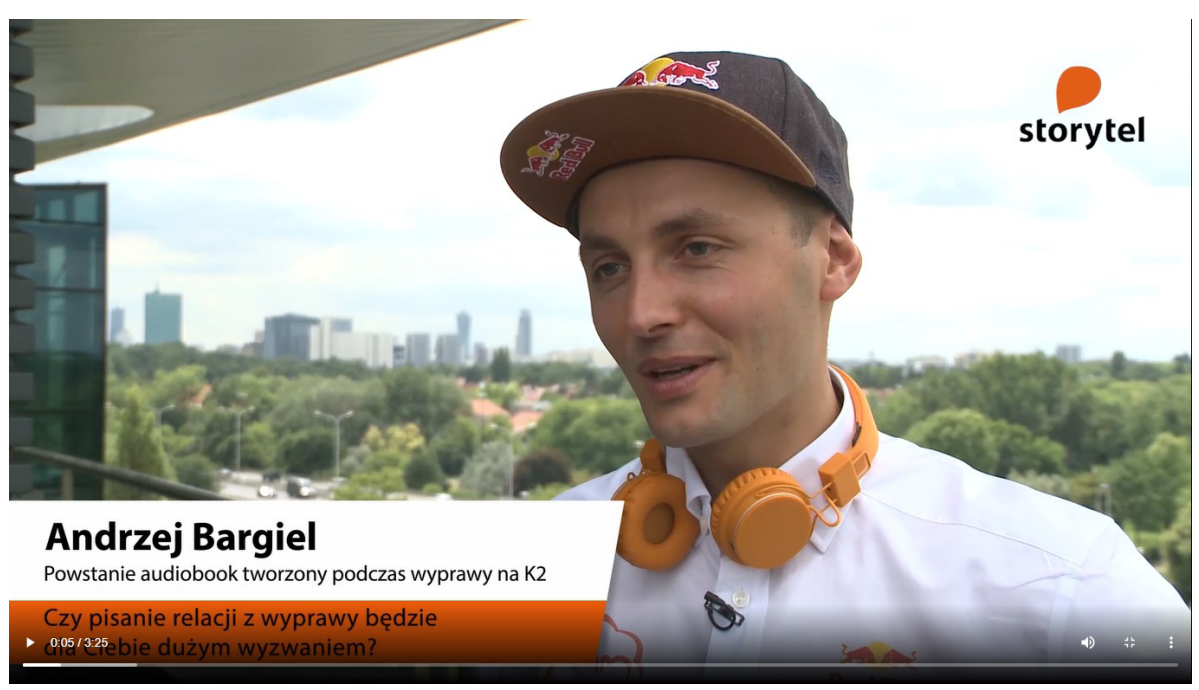

Grafika 7. Kadr z filmu promującego projekt „Atak na K2” Źródło: Atak2 ..., dz.cyt. (dostęp 11.09.2021 r.).

Bargiela, Marka Ognia oraz Piotra Pawlusa. Dodatkowo ponad 2 godziny różnych dźwięków nagrywanych podczas całej wyprawy - bicie serca i oddech Andrzeja podczas wyjść aklimatyzacyjnych, wiatr szalejący u podnóża szczytu K2, odgłosy miast w trakcie wyprawy, rozmowy Szerpów, latającego drona czy nawet muchy fruwającej w namiocie" ${ }^{52}$. Po otrzymaniu kolejnej części nagrań redakcja Storytel dokonywała odsłuchu dźwięków, obróbki i selekcji materiału, ustalenia, co będzie powiedziane przez lektora Macieja Kowalika, a co wyemitowane jako fragment wypowiedzi Bargiela lub kogoś z jego ekipy wspinaczkowej. Następnie nagrywano potrzebne elementy słuchowiska i montowano całość wraz z oprawą muzyczną. Taki materiał szybko pojawiał się na stronie serialu audio (dostęp poprzez aplikację Storytel). A zatem odcinek słuchowiska składał się z wypowiedzi i dialogów ekipy wspinaczkowej, nagrań lektora, dodatkowych dźwięków i efektów tła nagranych podczas wyprawy oraz muzyki. Warte zauważenia są również materiały filmowe i graficzne promujące serial audio. Jeden z filmów jest formą krótkiego wywiadu z Andrzejem Bargielem, który opowiada o swoim planie zdobycia K2

${ }^{52}$ Słuchowisko z wyprawy Andrzeja Bargiela hitem Storytel, „Portal medialny.pl” z 5.08.2018 r., http://www.portalmedialny.pl/art/65064/suchowisko-z-wyprawy-andrzejabargiela-hitem-storytel (dostęp 8.09.2021 r.). 
wraz ze zjazdem na nartach ze szczytu. Mówi też tu o samym pomyśle nagrań ze wspinaczki. Podkreśla, że pragnie w ten sposób przybliżyć słuchaczom klimat tejże wędrówki i emocje panujące podczas wspinaczki. „Myślę, że przez tę naszą realizacje - pamiętnik, audiobook z wyprawy - przeniesiemy troszeczkę klimatu górskiego. I ludzie będą mogli sobie posłuchać, przenieść się w tamto miejsce"53 mówi Andrzej Bargiel w filmie promującym projekt. Grafika 7 przedstawia klatkę filmową z materiału wideo.

Słuchowisko posiada również zwiastun dźwiękowy dostępny na platformie YouTube wraz z grafiką przedstawiającą fotografię bohatera projektu (grafika 8).

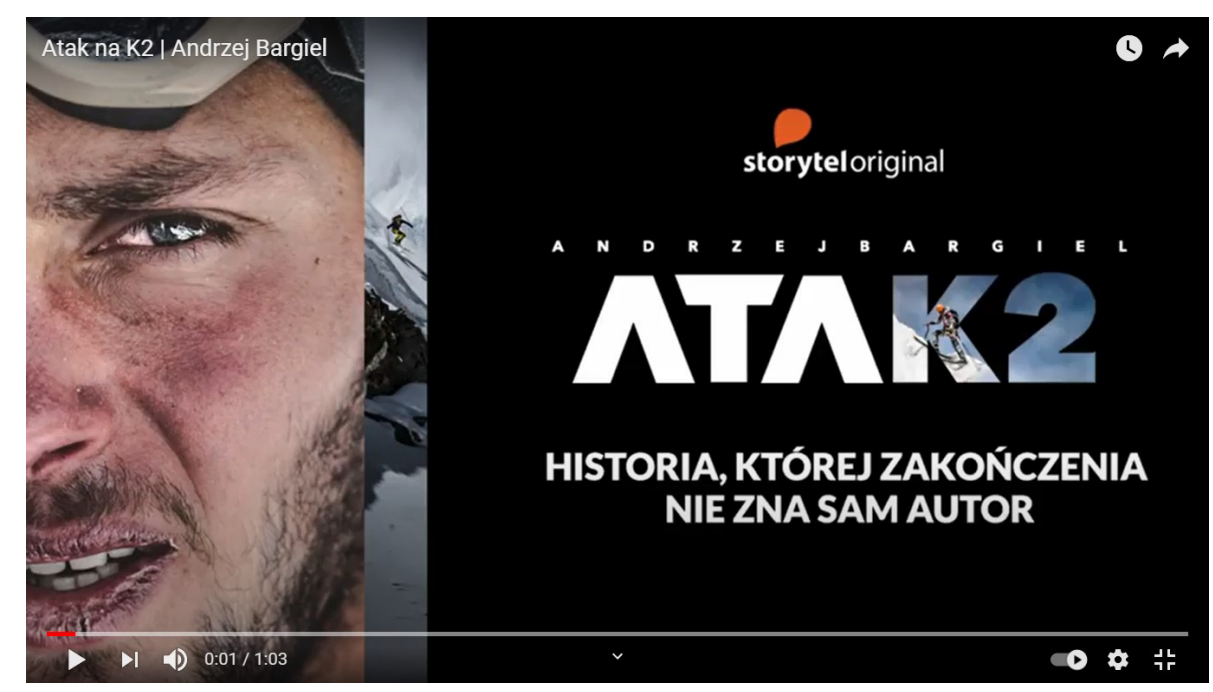

Grafika 8. Kadr ze zwiastuna „Ataku na K2”

Źródło: Atak na K2. Andrzej Bargiel, „YouTube” z 4.07.2018 r., https://www.youtube. com/watch?v=X0OunIRDY-E\&t=37s (dostęp 11.09.2021 r.)

Serial audio „Atak na K2” był szeroko promowany w mediach i spotkał się z bardzo dobrym odbiorem wśród słuchaczy. W ciągu pierwszego miesiąca od momentu powstania produkcji kampania promocyjna prowadzona poprzez social media przyniosła ponad 1000 wzmianek (Facebook, Twitter, Instagram) i osiągnęła zasięg na poziomie 20000000 odbiorców. Stronę internetową serialu audio w tym czasie odwiedziło ponad 50000 unikalnych użytkowników.

${ }^{53}$ Atak2, „Atak2.Storytel.pl”, https://atak2.storytel.pl/ (dostęp 11.09.2021 r.). 
Słuchowisko utrzymało się wtedy w czołówce najpopularniejszych produkcji Storytel $^{54}$. Serialu audio można słuchać odpłatnie w aplikacji Storytel.

\section{WNIOSKI}

Analiza wybranych pięciu polskojęzycznych seriali audio pozwala na udzielenie odpowiedzi na pytanie postawione we wstępie artykułu: Jaka jest charakterystyka i zawartość omawianych polskojęzycznych przykładów serialu audio? Zaprezentowane cykle są dostępne (głównie odpłatnie) w aplikacjach dystrybutorów sieci cyfrowych Storytel i Empik.Go. Każdy z seriali audio dostępny jest w formie odcinkowej. Wszystkie posiadają pewną formę promocji wideo, realizowaną na bardzo wysokim poziomie technicznym. W większości przypadków materiały promocyjne trafiają na YouTube - poza tą platformą umieszczone są jedynie filmowe materiały promocyjne do serialu audio „Lalka”. Warto podkreślić, że materiały promocyjne dwóch seriali audio dostępnych na kanale YouTube posiadają formę zwiastuna wideo, odcinka filmowego lub teledysku („Autor Bestsellerów”, „Random”). Każdy z omawianych pięciu seriali audio posiada też graficzne materiały promocyjne $\mathrm{w}$ standardzie nawiązującym do plakatu filmowego. Zebrane dane jednoznacznie potwierdzają hipotezę 1 („Seriale audio są nowoczesną formą słuchowiska radiowego, wykorzystując formy multimedialne"). Biorąc pod uwagę samą treść i charakterystykę analizowanych seriali, audio należy zauważyć, że $\mathrm{w}$ trzech przypadkach powstały one na podstawie scenariusza pisanego specjalnie pod tę formę produkcji („Autor Bestesellerów”, „Random”, „Fakap”). „Lalka” oparta jest na powieści o tej samej nazwie, zaś „Atak na K2” łączy elementy autentycznych dźwięków i wypowiedzi (jak w reportażu/dokumencie radiowym) z narracją lektorską. Wszystkie z omawianych seriali audio zdaniem autorki tego artykułu przekazują interesujące treści o walorach rozrywkowych („Autor Bestsellerów”, „Fakap”, „Random”), edukacyjnych („Lalka”) lub informacyjnych z elementami edukacji („Atak na K2”). Jakość techniczną przeanalizowanych seriali audio oceniono na poziomie wysokim lub bardzo wysokim. W czterech serialach audio występuje rozbudowana i złożona oprawa muzyczna oraz efekty dźwiękowe. Tylko w „Autorze Bestsellerów” montaż pozbawiony jest dodatkowej oprawy

${ }^{54}$ Zob. Słuchowisko z wyprawy Andrzeja Bargiela hitem Storytel, „Głos kultury”, https:// www.gloskultury.pl/sluchowisko-z-wyprawy-andrzeja-bargiela-hitem-storytel/ (dostęp: 11.09.2021 r.). 
muzycznej i dźwiękowej - tworzywem jest sam głos aktora. W czterech serialach audio występują znani Polscy aktorzy („Autor Bestsellerów”, „Random”, „Lalka”, „Fakap”). W jednym z seriali („Atak na K2”) główny bohater jest autentyczną osobą - jest to wspinacz Andrzej Bargiel. W słuchowisku „Fakap” poza gwiazdorską obsadą aktorską w bohaterów wcielają się znani komicy (stand-uperzy). Powyższe analizy pozwalają również na potwierdzenie hipotezy 2 („Seriale audio są przygotowane w wysokiej jakości merytorycznej i technicznej").

\section{Każdy z seriali audio dostępny jest w formie odcinkowej. Wszystkie posiadają pewną formę promocji wideo, realizowaną na bardzo wysokim poziomie technicznym}

Na podstawie dokonanej analizy można wskazać główne cechy serialu audio w Polsce oraz zidentyfikować te z nich, które wskazują na to, że seriale audio można nazwać nowoczesnymi słuchowiskami. Można również wymienić te cechy, które odróżniają seriale audio od tradycyjnych słuchowisk radiowych:

1. Seriale audio są produkowane przez firmy będące dystrybutorami treści cyfrowych - nie są one emitowane w rozgłośniach radiowych (tak jak ma to miejsce w przypadku tradycyjnych słuchowisk), a z wykorzystaniem platform streamingowych, aplikacji i stron internetowych (czasem YouTube).

2. Forma przekazu dźwiękowego w serialach audio jest ciekawa i nowoczesna, zarówno pod względem formatu, jak i jakości technicznej czy rozmachu realizacyjnego materiałów audio. W serialu audio mamy często bardziej rozbudowaną i realistyczną realizację dźwiękową niż w tradycyjnych słuchowiskach. Wykorzystane dźwięki, efekty, muzyka, mogą dla odbiorcy przypominać pełną ścieżkę dźwiękową z produkcji filmowej.

3. W bohaterów seriali audio wcielają się znani aktorzy, w pierwszej kolejności kojarzeni z produkcjami filmowymi i serialami, ale także np. komicy lub inne znane osoby. W tradycyjnych słuchowiskach są to wyłącznie lektorzy i aktorzy, często związani jedynie z radiem lub ewentualnie światem teatru.

4. Serial audio potrafi łączyć słuchowisko $\mathrm{z}$ elementami form nawiązujących do reportażu/dokumentu, dążąc do zatarcia granicy między fikcją a światem 
realnym i budując $\mathrm{w}$ ten sposób silniejszy związek emocjonalny z odbiorcą. Podobne zabiegi nie mają miejsca w tradycyjnych słuchowiskach, gdzie zawsze wiemy, że mamy do czynienia z fikcyjnymi, fabularnymi opowieściami.

\section{Seriale audio stały się zatem czymś więcej niż samą formą dźwiękową. Potrafią swobodnie czerpać ze sztuk wizualnych i w szerszym ujęciu łączyć elementy dźwiękowe, filmowe i graficzne dla pobudzenia wyobraźni i wzmocnienia sugestywności eksponowanego przekazu audio. Doskonale realizują zatem idee konwergencji mediów}

5. Projekty seriali audio wyróżniają się rozbudowanymi formami promocji. Materiały promocyjne stanowią wysokiej jakości multimedialne materiały wideo oraz materiały graficzne. Formy multimedialne (filmowe) bywają elementem samego słuchowiska (jeden z odcinków serii) lub jego zwiastunem. Seriale audio stały się zatem czymś więcej niż samą formą dźwiękową. Potrafią swobodnie czerpać ze sztuk wizualnych i w szerszym ujęciu łączyć elementy dźwiękowe, filmowe i graficzne dla pobudzenia wyobraźni i wzmocnienia sugestywności eksponowanego przekazu audio. Doskonale realizują zatem idee konwergencji mediów. Słuchowiska tradycyjne nie zawierają form multimedialnych, ograniczając formy promocyjne do fragmentów audio, czy, w niektórych przypadkach, statycznych grafik. Seriale audio doskonale wpisują się zatem w bycie konglomeratami gatunkowymi, które medioznawca Grażyna Stachyra opisuje jako „składające się z elementów tekstowych, obrazowych czy filmowych"55. Badaczka odróżnia je od tradycyjnych gatunków radiowych będących „kolekcjami form audialnych"56.

${ }^{55}$ G. Stachyra, Współczesne gatunki radiowe jako konglomeraty i kolekcje, [w]: E-gatunki. Dziennikarz w nowej przestrzeni komunikowania, red. W. Godzic, Z. Bauer, Warszawa 2015, s. 25.

${ }^{56}$ Tamże, s. 25. 


\section{Seriale audio doskonale wpisują się zatem w bycie konglomeratami gatunkowymi}

6. Język używany przez bohaterów seriali audio jest często bardziej potoczny, ma na celu osiągnięcie pewnego realizmu i zbliżenie do odbiorcy, zawiera wyrażenia zaczerpnięte ze slangu np. młodzieżowego czy wulgaryzmy. Język słuchowisk tradycyjnych jest często bardziej stonowany, mniej potoczny, rzadko zdarzają się wulgaryzmy. Tradycyjne słuchowisko, nawet fabularne, w odbiorze w warstwie aktorskiej czy dykcji, bliższe jest sztukom teatralnym.

7. Dostęp do seriali audio w większości przypadków wymaga płatnej subskrypcji i wykupienia abonamentu w jednej z platform streamingowych. Tradycyjne słuchowiska radiowe emitowane $\mathrm{w}$ radiu dostępne są powszechnie bez ograniczeń.

\section{Polskojęzyczne seriale audio stanowią nowoczesną formę słuchowiska, zyskując dla form audialnych nowe pokolenie słuchaczy}

\section{ZAKOŃCZENIE}

Polskojęzyczne seriale audio stanowią nowoczesną formę słuchowiska, zyskują dla form audialnych nowe pokolenie słuchaczy. Przekazują ciekawe treści o walorach rozrywkowych, edukacyjnych i informacyjnych, kreując przekaz i często przyciągając odbiorców z wykorzystaniem zróżnicowanych medialnie, nowoczesnych i interaktywnych form promocji. Zawsze jednak to przekaz stricte audialny jest na pierwszym miejscu. Seriale audio przygotowywane są w pełni profesjonalnie i z wykorzystaniem nowoczesnych technik dźwiękowych. Celem niniejszego artykułu było ukazanie i scharakteryzowanie specyfiki polskiego serialu audio oraz wskazanie w jaki sposób realizuje on ideę nowoczesnych słuchowisk. Problematyka serialu audio jest warta dalszych rozważań, szczególnie w ujęciu badań nad odbiorem przez słuchaczy tejże formy. Do obszarów wartych badań 
warto wskazać m. in.: wpływ seriali audio na odbiorców, postrzeganie tej formy słuchowiska czy źródła fenomenu form audialnych dedykowanych do odbioru w internecie, które popularnością zdają się przewyższać słuchowiska dostępne w eterze. Autorka artykułu ma nadzieję, że opracowanie stanowić może przyczynek do dalszych badań naukowych wśród badaczy zajmujących się przekazem audio, słuchowiskiem, radiem i konwergencją mediów.

\section{BIBLIOGRAFIA}

\#2 Fakap. Kołcz Lajk - Oryginalny Serial Empik Go, „Empik.com”, https://www.empik.com/ 2-fakap-kolcz-lajk-oryginalny-serial-empik-go-sipika-juliusz,p1264916919,ebookii-mp3-p (dostęp 8.09.2021 r.).

Albińska K., «Teatr do słuchania», «literatura do grania», «kino dla ucha»: o rodowodzie gatunkowym słuchowiska radiowego, „Kultura i Historia” 2012, nr 21, http://kulturaihistoria.umcs.lublin.pl/archives/3400 (dostęp 3.06.2021 r.).

Albińska K., Słuchowisko w erze «nowego radia»: o współczesnym sposobie istnienia teatru audialnego i jego statusie, „Kultura i Edukacja” 2011, nr 1, s. 142-160.

Atak2, „Atak2.Storytel.pl”, https://atak2.storytel.pl/ (dostęp 11.09.2021 r.).

Atak na K2. Andrzej Bargiel, „YouTube” z 4.07.2018 r., https://www.youtube.com/wat$\mathrm{ch} ? \mathrm{v}=$ X0OunIRDY-E\&t=37s (dostęp 11.09.2021 r.)

Audio drama weekly discussion thread, „Reddit.com”, https://www.reddit.com/r/audiodrama/comments/p924zz/raudiodrama_weekly_discussion_thread_august_22/ (dostęp 27.08.2021 r.).

Bachura-Wojtasik J., Matusiak E., Dźwiękowa sztuka elitarna. Szkic o słuchowisku poetyckim na podstawie wybranych utworów Janusza Kukuły, „Media-Kultura-Komunikacja Społeczna" 2020, t. 3, https://czasopisma.uwm.edu.pl/index.php/mkks/article/ view/6621 (dostęp 3.06.2021 r.), s. 111-126.

Bachura J., Pawlik A., Słuchowisko i jego „,anatomia”, [w:] red. E. Pleszkun-Olejniczakowa, J. Bachura, A. Pawlik, Dwa Teatry. Studia z zakresu teorii i interpretacji sztuki słuchowiskowej, Toruń 2011, s. 141-179.

Bauer Z., Wstęp 2, [w]: E-gatunki. Dziennikarz w nowej przestrzeni komunikowania, red. W. Godzic, Z. Bauer, Warszawa 2015, s. 15-24.

Biewen J., Inroduction [w:] Reality Radio. Telling true stories in sounds, University of North Carolina, Chapel Hill, North Carolina 2010.

"Dni powszednie państwa Kowalskich". Pierwsza powieść napisana dla Polskiego Radia, „Polskieradio.pl”, https://www.polskieradio.pl/39/156/Artykul/2839233,Dni-powszednie-panstwa-Kowalskich-Pierwsza-powiesc-napisana-dla-Polskiego-Radia (dostęp: 6.11.2021 r.).

Empik Go: druga edycja konkursu na scenariusz serialu audio, „Filmweb.pl”, https://www. filmweb.pl/news/Empik+Go\%3A+Druga+edycja+konkursu+na+scenariusz+serialu +audio-143279 (dostęp 30.08.2021 r.). 
«Fakap». Pierwszy komediowy serial audio w Polsce zadebiutuje w Empik Go, „Empik.com”, https://news.empik.com/129956-fakap-pierwszy-komediowy-serial-audio-wpolsce-zadebiutuje-w-empik-go (dostęp 8.09.2021 r.).

Głos młodego pokolenia - Natasza Parzymies opowiada o życiu młodych ludzi w trudnych czasach pandemii, „Storytel.pl”, https://storytelpl.prowly.com/132060-glosmlodego-pokolenia-natasza-parzymies-opowiada-o-zyciu-mlodych-ludzi-nbspwtrudnych-czasach-pandemii (dostęp 7.09.2021 r.).

Gwiazdy ekranu w serialach do słuchania, „Storytel.pl”, https://storytelpl.prowly.co$\mathrm{m} / 38809$-gwiazdy-ekranu-w-serialach-do-sluchania (dostęp 30.08.2021 r.).

Kaziów M., $O$ dziele radiowym. $Z$ zagadnień estetyki oryginalnego słuchowiska. Wrocław Warszawa - Kraków - Gdańsk 1973.

Lalka Bolesława Prusa odczytana na nowo w serialu audio. Wieniawa i Woronowicz w rolach głównych, „Empik.com” z 24.09.2020 r., https://news.empik.com/109861-lalka-boleslawa-prusa-odczytana-na-nowo-w-serialu-audio-wieniawa-i-woronowiczw-rolach-glownych (dostęp 8.09.2021 r.).

Łastowiecki J., Specyfika odbioru słuchowiska radiowego, Toruń 2019.

Łastowiecki J., Teatr Polskiego Radia jako Wielka Wspólnota OSOBNYCH. Spotkanie z Andrzejem Mularczykiem, „Tekstualia” 2013, nr 1 (32), s. 21-24.

Łastowiecki J., Wielka wspólnota osobnych, „Tekstualia” 2013, nr 1 (32), s. 39-52.

Matysiakowie - o audycji, „Polskieradio.pl”, https://www.polskieradio.pl/241/4717/Artykul/1598248,Matysiakowie-o-audycji (dostęp: 6.11.2021 r.).

Radio drama, „Wikipedia”, https://en.wikipedia.org/wiki/Radio_drama?fbclid=IwAR0_ Lw3tkHwxJzV2jiH3yzvCmQOrEzDwYmW-seac_2A3oKqMZLCKfHSawiA (dostęp 27.08.2021 r.).

Pisarek W., Słownik Terminologii Medialnej, Kraków 2006.

Pleszkun-Olejniczakowa E., Jak jest zrobione słuchowisko? O morfologii i znaczeniu, o kreacji i znaku, [w:] red. E. Pleszkun-Olejniczakowa, J. Bachura, A. Pawlik, Dwa teatry. Studia z zakresu teorii i interpretacji sztuki słuchowiskowej, Toruń 2011, s. 59-140.

Ptaszek G., W stronę bezgatunkowości mediów? O funkcji gatunków medialnych w procesie odbioru, [w]: Gatunki i formaty we współczesnych mediach, red. W. Godzic, A. Kozieł, J. Szylko-Kwas, Warszawa 2015, s. 35-51.

Random - pierwszy polski serial łączacy słuchowisko i film od 14 lutego w Storytel, https:// www.wirtualnemedia.pl/artykul/random-serial-laczacy-sluchowisko-i-filmstorytel-kiedy-premiera (dostęp 7.09.2021 r.).

Random, „Storytel.pl”, https://www.storytel.com/pl/pl/books/2173674-Random (dostęp 5.09.2021 r.).

Seriale audio czego warto słuchać tej jesieni, „Elle.pl”, https://www.elle.pl/artykul/seriale-audio-czego-warto-sluchac-tej-jesieni (dostęp 30.08.2021 r.).

Słownik wiedzy o mediach, red. E. Chudziński, Warszawa-Bielsko Biała 2007.

Słuchowisko z wyprawy Andrzeja Bargiela hitem Storytel, „Portal medialny.pl” z 5.08. 2018 r., http://www.portalmedialny.pl/art/65064/suchowisko-z-wyprawyandrzeja-bargiela-hitem-storytel (dostęp 8.09.2021 r.). 
Słuchowisko z wyprawy Andrzeja Bargiela hitem Storytel, „Głos kultury”, https://www. gloskultury.pl/sluchowisko-z-wyprawy-andrzeja-bargiela-hitem-storytel/ (dostęp 11.09.2021 r.).

Stachyra G., Współczesne gatunki radiowe jako konglomeraty i kolekcje, [w]: E-gatunki. Dziennikarz w nowej przestrzeni komunikowania, red. W. Godzic, Z. Bauer, Warszawa 2015, s. 25-49.

Stachyra G., Perspektywy badania współczesnej genologii radiowej, „Acta Universitatis Lodziensis. Folia Litteraria Polonica" 2017, nr 39, s. 49-71.

Stand-uper, „Słownik języka polskiego”, https://sjp.pl/standuper (dostęp 8.09.2021 r.).

Storytel czeka na wasze powieści w odcinkach, „Blog Poland Storytel.com”, https:// blog-poland.storytel.com/2017/07/18/storytel-czeka-na-wasze-powiesci-wodcinkach/\#more-763 (dostęp: 28.08.2021 r.).

Storytel jak Netflix, „Storytel.pl”, https://storytelpl.prowly.com/8587-storytel-jak-netflix (dostęp 28.08.2021 r.).

Storytel z niezwykła premierq serialowa, Zobacz zwiastun «Autora Bestsellerów». Wideo, „Sotrytel.pl”, https://storytelpl.prowly.com/38059-storytel-z-niezwykla-premiera-s erialowa-zobacz-zwiastun-autora-bestsellerow-wideo (dostęp 5.09.2021 r.).

Storytel, „Storytel.pl”, https://www.storytel.com/pl/pl/o-storytel (dostęp 27.08.2021 r.). Szlachta A., Językowe wykładniki kreacji świata przedstawionego w słuchowisku Krzysztofa Bizia pt. «Fotoplastykon», „Studia Językoznawcze” 2019, t. 18, https://wnus.edu.pl/ $\mathrm{sj} / \mathrm{pl} /$ issue/1163/article/18514/ (dostęp 3.06.2021 r.), s. 143-162.

Treasure J., Sound business. How to use sound to grow profits and brand value (2nd ed.), „Journal of Business Research” 2011, nr 49(2), s. 193-211.

W Jezioranach, „Polskieradio.pl”, https://www.polskieradio.pl/357/7234/ (dostęp: 6.11.2021 r.).

\section{Biogram}

Anna Gawrońska-Piotrowska - dziennikarz radiowy. Asystent w Instytucie Edukacji Medialnej i Dziennikarstwa UKSW w Warszawie (Wydział Teologiczny). Absolwentka Instytutu Wiedzy o Kulturze na Wydziale Teologicznym UKSW (specjalizacja: zarządzanie w kulturze, dyplom z wyróżnieniem). Doktorantka Teologii Środków Społecznego Przekazu na Wydziale Teologicznym UKSW. Pracowała w Radiu Józef (Plus Warszawa) i Radiu Warszawa, była związana z Polskim Radiem (Studio Reportażu i Dokumentu Polskiego Radia, Redakcja Programów Katolickich Polskiego Radia, Program 2 Polskiego Radia, Program 1 Polskiego Radia). Laureatka międzynarodowych i ogólnopolskich konkursów z dziedziny reportażu radiowego, m.in. I Nagroda na Międzynarodowym Katolickim Festiwalu Filmów i Multimediów Niepokalanów 2011. W Instytucie Edukacji Medialnej i Dziennikarstwa UKSW prowadzi zajęcia z podstaw dziennikarstwa radiowego, warsztatu reportera i prezentera radiowego, form dokumentalnych w radiu. Redaktor naczelna akademickiego Radia UKSW.

ORCID: 0000-0002-2403-6900 